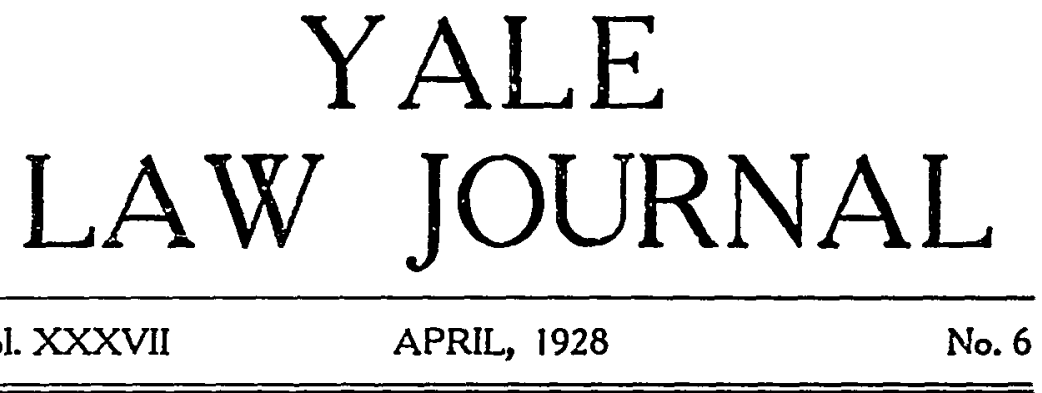

\title{
LEGAL THEORY AND REAL PROPERTY MORTGAGES
}

\section{Wesley A. Sturges and Samuel O. Clark}

Judging by the introductory material of the standard casebooks and texts on the subject of mortgages, the student of the law of mortgages begins his study with a consideration of "The Nature of $a$ Mortgage." $\mathrm{He}$ is first introduced to "the common law mortgage," to "the common law theory of mortgage." His first reading of case opinions on this topic, supplemented, for instance, by Professor Pomeroy's text, will inform him upon "The Original or English Doctrine," which, the student discovers, comprehends "a purely legal theory" and an "equitable theory" of the nature of "an ordinary mortgage." Thereafter the student is informed concerning "The American Doctrine" and of its comparison with the English "system." ?

Concerning "The Original or English Doctrine" we will quote Professor Pomeroy for what we believe to be commonly accepted learning on the subject:

"At the common law [clearly having reference to English "common law" only] the ordinary mortgage was to all intents and purposes a conveyrance of the legal estate. A mortgage in fee immediately vested the mortgagee with the legal title, subject, however, to be defeated by the mortgagor's performing the condition by paying the money upon the prescribed pay-day. If on that very day the mortgagor performed the condition by paying the money, he thereby put an end to the mortgagee's es. tate; the legal estate was revested in himself, and with it he had the right at once to re-enter upon the land and to recover its possession by an appropriate action at law. But if the mortgagor for any reason suffered the pay-day to go by without paying or tendering the amount due, all his right was utterly and forever lost; the estate of the mortgagee which had before been upon condition, now became absolute, with all the features and

13 PoMIERoY, Equity JURISPRUdence (4th ed. 1918) §§ 1179-1185.

23 ibid. $\$ \S 1186-1190$. 
incidents of absolute legal ownership. This purely legal theory of the mortgage has continued in force in England to the present day, until the existing judicature act ${ }^{3}$ went into operation; and during that interval it has constantly prevailed and been acted upon in the English courts of law without any modification except that introduced by a statute passed during the reign of George II." 4

\section{Professor Durfee has also written as follows:}

"In other words, the original common law theory of the mortgage was that there were no mortgages. Those conveyances which the Court of Chancery called mortgages the courts of common law called conditional conveyances and these courts had no special rules for them which could be called a law of mortgages'. As to the operation of the rules of conditional estates upon the mortgage, it is enough to say that, before default, the mortgagee was vested with an estate upon condition subsequent while the mortgagor had a right of re-entry upon performance of the condition and that, after default, the mortgagee had an absolute estate while the mortgagor had no rights in the land whatever." 5

In further exposition of the English system we will set forth the following statement from Professor Pomeroy's report on the English "equitable theory" of "an ordinary mortgage":

"While the mortgagee is still regarded at law as vested with the legal title followed by all of its incidents, the following general theory is established as a part of the equity jurisprudence. The mortgagor, both after and before a breach of the condition, is regarded as the real owner of the land subject to the lien of the mortgage, and liable to have all his estate, interest, and right finally cut off and destroyed by a foreclosure. Prior to such foreclosure, he is vested with an equitable estate in the land which has all the incidents of absolute ownership; it may be conveyed or devised, will descend to his heirs, may be cut up into lesser estates and generally be dealt with in the same manner as the absolute legal ownership, always subject, however, to the lien of the mortgage. On the other hand, the mortgage is regarded primarily as a security; the debt is the principal fact,

3 The reference is to that provision of the JUDICATURE ACT of 1873, 36 \& 37 Vict., c. $66, \S 25$, which provides that rules of equity shall provail over conflicting rules of law. From this the learned author concludes: "it seems to follow as a necessary consequence that the purely legal theory of the mortgage can no longer be enforced." 3 Pomeroy, op. cit. supru note $1, \$ 1179$, n. 2.

43 Pomeroy, op. cit. supra note $1, \$ 1179$. The statute referred to provided that in an action on the mortgage bond, or in ejectment to recover possession of the mortgaged land, the mortgagor might pay the mortgago debt, interest, and costs of the suit and obtain a reconveyance of tho mortgaged premises. (1734). 7 Geo. II, c. 20. This statute is explained by Professor Pomeroy in $\$ 1179$, n. 3 .

5 Durfee, The Lien or Equitable Theory of the Mortgage-Somo Goncralizations (1912) 10 MrCH. L. REv. 587, 592. 
and the mortgage is collateral thereto; the interest which it confers on the mortgagee is a lien on the land, and not an estote in the land; it is a thing in action, and may therefore be assigned and transferred without a conveyance of the land itself; it is personal assets, and on the death of the mortgagee it passes to his executor's or administrators, and not to his heirs." " (Italics are Professor Pomeroy's).

Professor Durfee's views regarding the English equitable theory seem to be in accord. ${ }^{7}$ Given the foregoing expositions of the two original English theories of mortgage the student anxiously reads on concerning their contemporaneous existence in English jurisprudence in order to grasp the English system. Professor Pomeroy explains the situation as follows:

"As these two conflicting theories have existed side by side, it follows that the rights, liabilities, and remedies of the mortgagor and the mortgagee in England have been very difierent when administered by the courts of law or the court of chancery. In law, the mortgagee is clothed with the entire legal estate, while the mortgagor has no estate whatever, and after a default no right except that given by the statute, mentioned in a former paragraph. ${ }^{8}$ In equity, the mortgagee has no estate, but only a lien, while the mortgagor is clothed with the equitable estate called the 'equity of redemption,' which is to all intents and purposes the full ownership, except that it is subject to be cut off and destroyed by a proceeding to enforce the mortgage. It should be carefully noticed that by this theory the mortgagor's estate is wholly an equitable one; neithci in cquity nor at lau" is he regarded as retaining the legal estate." " (Italics are Professor Pomeroy's).

The student is much perplexed with this series of words. What is this "entire legal estate" with which the mortgagee is "clothed" in law, whereas in equity the equitable estate with which the mortgagor is "clothed" "is to all intents and purposes the full ownership" except that it may be foreclosed? If the mortgagor does not retain the legal estate either at law or in equity, and if, in equity, the mortgagee has "no estate, but only a lien," where, in equity, is "the legal estate" if there is one? What is this "only a lien" which the mortgagee has, in equity, which is "no estate" in equity, but is "the legal title," in law? Otherwise noted, if we "vest" "only a lien," in equity, and "the entire legal estate," in law in a person, we have "the mortgrigee." If we "clothe" a person with "the equitable estate called the equity of redemption," in equity, "which is to all intents and purposes the full ownership" except that it may be foreclosed,

63 Poneroy, op. cit. supra note $1, \S 1181$.

7 Durfee, op. cit. supra note 5 , at 593.

8 See supra note 4.

93 POMERoY, op. cit. supra note 1, § 1182. 
and strip him of the "legal estate" both in law and in equity, we have "the mortgagor."

Most writers have neglected to particularize the relationship of these "two conflicting theories" which "existed side by side." Professor Durfee, however, approaches the problem in reporting on the equitable doctrine of mortgages "as it stood at the middle of the eighteenth century." He says :

"And at that time these doctrines, by reason of the practical supremacy of equity over law within the field of its activity, came to be . . . the really substantial 'law of mortgages' so recognized everywhere except in courts of law." ${ }^{10}$

Chancellor Kent has referred to the reforms by courts of equity as follows:

"the case of mortgages is one of the most splendid instances in the history of our jurisprudence, of the triumph of equitable principles over technical rules. . . . The doctrine, now regarded as a settled principle, was laid down in the reign of Charles I." ${ }^{11}$ (Italics are the writers').

How shall the student grasp the relationship of these two theories, "conflicting" as they are, but which "exist side by side," although, according to Chancellor Kent, equitable principles triumphed over technical rules, and according to Professor Durfee "these [equitable] doctrines came to be the really substantial 'law of mortgages,' so recognized everywhere, except in courts of law"? What does Chancellor Kent mean by his terms "principles" and "rules" 12 as used in his statement? Are they used synonymously? If so what does he mean by the proposition that "equitable principles" triumphed over "technical principles"?

10 Durfee, loc. cit. supra note 7.

114 Kent, Commentaries $* 158$.

12 Cf. definition of "rules" and "principles" by Dean Pound: "Rules, that is definite, detailed provisions for definite, detailed states of fact, aro the main reliance of the beginnings of law. In the maturity of law they are employed chiefly in situations where there is exceptional need of certainty in order to uphold the economic order. With the advent of legal writing and juristic theory in the transition from the strict law to equity and natural law, a second element develops and becomes a controlling factor in the administration of justice. In place of detailed rules precisely determining what shall take place upon a precisely detailed state of facts, reliance is had upon general premises for judicial and juristic reasoning. These legal principles, as we call them, are made use of to supply now rules, to interpret old ones, to meet new situations, to measure the scope and application of rules and standards and to reconcile them when they conflict or overlap." POUND, AN INTRODUCTION TO THE PHILOSOPHY OF LAW (1925) 115. But see Cook, The Present Status of the Laok of Mutulality Rule (1927) 36 YALE LAw JovrNaL 897, 912: "Every attempt to rcduce the law in a given field to a rule which can be applied automatically to really new situations by the processes of deductive logic is of necessity foredoomed to failure." 
By saying that "equitable rules" triumphed over "technical rules" or that "equitable rules" triumphed over "technical principles"? By any chance does the term "equitable" here have a broad ethical meaning of fairness? If the term refers to courts of equity, does he mean that the triumph occurred in courts of equity only? And to what does the term "technical rules" refer: rules of courts of equity, or of courts of law, or of both? If the term "principles," as here used by Chancellor Kent, is to be distinguished from the term "rules," as he here uses it, what distinction is intended?

Let us turn to Professor Durfee's comment for particulars. He states, as we have noted, that "equitable doctrines" became "the really substantial 'law of mortgages'," by which latter term it is apparent that he means those special rules of the court of Chancery concerning those conveyances which it called mortgages, ${ }^{13}$ as distinguished from the original common law theory of mortgage which he states was that there were no mortgages. ${ }^{24}$ In other words, "the really substantial "law of mortgages" existed only in the Court of Chancery. However, the student is uncertain whether Professor Durfee intends that his terms "doctrines" and "law" shall be understood to have the same or different meanings. If the terms are to be understood synonymously, then the equitable doctrines come to be the "really substantial doctrine of mortgage" in equity; and the equitable law came to be the "really substantial 'law of mortgages' " in equity, and the equitable law came to be the "really substantial doctrine" of mortgages in equity, and this was "recognized everywhere except in courts of law." If Professor Durfee does not intend that these terms shall have identical reference, what distinctions shall be understood? The student is likewise left to uncertain inferences by Professor Durfee's proposition that "equitable doctrines" became "the really substantial "law of mortgages'" by reason of "the practical supremacy of equity ["law" or "doctrine," or both, or neither?] within the field of its activity." And what is this campus of equity activity, if "the really substantial 'law of mortgages'" was not so recognized by the courts of law? Is that which was recognized by the courts of law within or outside the "practical supremacy of equity"? When it is stated that "equitable doctrines" came to be "the really substantial "law of mortgages"," is it intended that once upon a time these "equitable doctrines" were not such "law"?

But what shall it profit an American student of the law of mortgages to acquire any clear, certain, or specific understanding of "The Original or English Doctrine," the doctrine of the English courts of law which "conflicts" with, but "exists side by

$\overline{13}$ Durfee, loc cit. supra note 7 .

14 Durfee, loc. cit. supra note 5. 
side" with the "equitable doctrine," which, in turn, was laid down in the reign of Charles $I$, and which, as "equitable principles," triumphed over "technical rules," and became "the really substantial 'law of mortgages', so recognized everywhere except in courts of law"? If it is intended that the terms "the common law mortgage" or "the common law theory of mortgage," refer to the English law courts only, can they be accurately appreciated if they are taken from their relative position with respect to the English "equitable doctrine"? If it is suggested or taught that the common law mortgage, or the common law theory of mortgage, was brought to or originally adopted by at least some of the courts of the American states, is it intended that "the really substantial 'law of mortgages'" was likewise adopted by American courts? When Professor Lloyd states that "to America the colonists brought the law of mortgages very much as they found it in the mother country," ${ }^{15}$ does he intend to include equity-law or "equity doctrine"? (Italics are the writers'). When Mr. Jones, in the 7th edition of his book on mortgages states that "the English doctrine of the nature of mortgages, with slight qualifications, prevails east of the Mississippi river, in a large majority of the states; while west of the Mississippi, except only in the states of Missouri and Arkansas, the doctrine everywhere prevails that a mortgage passes no legal estate or right of possession," " what does he mean by "the English doctrine" as he uses the term? Does it include "the equity doctrine"? Again, are Mr. Lloyd and Mr. Jones reporting on the same matter although one uses the term "the law" of England, and the other refers to "the English doctrine"?

Professor Pomeroy discusses this question more at length and apparently he is not in complete accord with the writers last mentioned. He says:

"The English system has not been adopted to its full extent in any of the American states. Two entirely different methods of viewing the mortage have become established in the states of this country, and the states themselves must be separated into two great classes with respect to their adoption of one or the other of these methods: 1 . In nearly half of the states and territories the conflict between the legal and equitable conceptions is entirely removed. The legal theory of mortgages has been abandoned, and the equity theory has been left in full force, furnishing a single and uniform collection of rules, recognized and administered, so far as necessary, alike by courts of law and of equity. The mortgage is not a conveyance; it confers no estate in the land. It simply creates a lien on the land as security for the debt due. The mortgagor's estate, instead of being equitable, an equity of redemption, is, for all purposes, and between all

${ }_{15}$ Lloyd, Mortgages-the Genesis of the Lien Theory (1923) 32 YALE LAW JoURNAL 233, 240.

161 Jones, Moptgages (7th ed. 1915) § 59. 
parties, the legal estate, but encumbered by the lien created by the mortgage. This simple conception is carried out with all its consequences, not only as between the immediate parties, but as between all persons who have or acquire any interest in or claim upon the mortgage itself or the land which is subject to the mortgage. 2. The second method, which prevails in the residue of the states and territories, may be briefly described as follows: Between the immediate parties - the mortgagor and mortgagee and persons holding under them-the legal conception is acknowledged, and the legal rights and duties flowing from the mortgage as a conveyance of the legal estate are recognized and enforced by the courts of law. But as between the mortgagor and his representatives and all other persons not holding under or through the mortgagee, the legal conception has bcen abandoned, and the equity view has been adopted by all courts, of law as well as of equity. Finally, the equity theory erists, is in fact the only one administered, and is applied by them to all parties in the same manner and to the same eatent as by the court of chancery in England." 18 (Italics are the writer's').

It may be noted at the outset that Professor Pomeroy here refers to the conflict between the legal and equitable canceptions of the English system. Is this term "conceptions" intended to be synonymous with the terms "theories" and "doctrines" which we have heretofore observed? Is this term synonymous with "the law," or "the really substantial "law of mortgages'," which terms we have already observed? And are the legal and equitable "conceptions" in question abstractions of a high degree ${ }^{18}$ like the conceptions of blessedness, propricty, and goodness?

17 I PoMrerox, op. cit. supra note $1, \S 163$. But compare the following remarks by equity covirts: "A mortgage is something more than a mere lien . . . As between mortgagor and mortgagee, the fee of the estate passes to the mortgagee, and he may, unless he has stipulated to the contrary, at once enter or bring an action of ejectment to recover possession." Trustees of Jefferson College $\checkmark$. Dickson, 1 Freem. Ch. 474, 483 (Aliss. 1840). "This court [of equity] will not prevent a mortgagee from taling possession of the mortgage premises, or, if he be in possession, deprive him of that possession as long as there is anything due on the mortgage." Schwarz v. Sears, Walker's Ch. 170, 172 (Mich. 1843). "The mortgagee is entitled to possession of the property immediately upon the exceution of the mortgage. . . ." Brown v. Stewart, 1 Ch. Dec. 87, 92 (Mrd. 1847).

18 Concededly, most if not all terms are more or less abstractions. The following quotation is suggestive: "The 'man in his whole life history' is an abstraction compared to the 'man in one such moment.' There are, therefore, three different meanings for the notion of a particular man, Julius Caesar, for example. The word 'Caesar' may mean 'Caesar in some one occasion of his existence'; this is the most concrete of all meanings. The word 'Caesar' may mean 'the historic route of Caesar's life from his Caesarian birth to his Caesarian assassination'. The word 'Caesar' may mean 'the common form or pattern, repeated in each occasion of Caesar's life'. You may legitimately choose any one of these meanings; but when you have made your choice, you must in that context stick to it." WhItEHEAd, STMibolisai, Its MIEANING AND EFreCT (1927) 26. Also see Bertrand Russelc, Philosophy (1927) 53. 
Professor Pomeroy appears to say that the following formula fits nearly half of the American states: The English system, with its conflicting conceptions, existing side by side, minus the legal theory equals "the equity theory . . . left in full force" and "furnishing a single and uniform collection of rules, recognized and administered, so far as necessary, alike by courts of law and equity." But if "the legal theory" is substracted from "the legal and equitable conceptions" of the English system, how can the remainder be "the equity theory . . . left in full force" unless "the equity theory" in remainder is conceived of as the "equitable conception" and unless "the legal theory" is conceived of as the "legal conception" of the English system? If such conceiving is had, what is this equitable conception in remainder which does not any longer exist in conflict with and side by side with "the legal theory," or the "legal conception," of the English system? Professor Pomeroy also states that this readjustment of conceptions away from the English system furnishes a uniform collection of mules administered alike by courts of law and equity as far as necessary. Does Professor Pomeroy intend to suggest that $a$ uniform collection of rules can not be found in the other half of the states, or that $a$ uniform collection of rules can not be found in all of the states? Or does he refer to a collection of uniform rules "furnished by" a uniform conception of the nature of a mortgage?

As respects the "residue of the states and territories," Professor Pomeroy reports that "the legal conception is acknowledged," "between the immediate parties," but otherwise "the legal conception has been abandoned, and the equity view adopted by all courts, of law as well as of equity" and finally, that "the equity theory exists, is in fact the only one administered by courts of equitable jurisdiction, and is applied by them to all parties in the same manner and to the same extent as by the court of chancery in England." 10 As a consequence may it be expected that there is or that there is not a uniform collection of rules in these states administered alike by courts of law and equity as may be necessary? Granted that "the legal conception is acknowledged" between the immediate parties, does the conflicting equitable conception exist by its side in such cases? And how can "the equity theory" be the "only one administered by courts of equitable jurisdiction" and be applied by them to all parties "in the same manner and to the same extent as by the court of chancery in England," if "the legal conception is acknowledged" between the immediate parties-or is it not so "acknowledged" by the courts of equitable jurisdiction of these states? If the legal conception "has been abandoned" in cases not between the im. mediate parties, how can "the equity theory" be administered by

101 Pomeroy, loc. cit. supra note 17. 
the courts of equitable jurisdiction of these states "in the same manner and to the same extent as by the court of chancery in England," if and as "the legal conception" has not been so abandoned there but still conflicts with and exists side by side with the equitable theory?

Professor Durfee offers less encouragement to simple classification of the American states. Writing in 1912, he says:

"There are probably no two states in which the law of mortgages is the same in all particulars, but they may be broadly classified into three groups: (1) those in which the mortgage is held to pass the legal titie to the land at its execution; (2) those in which it is held to pass the title on default, and (3) those in which it is held to pass no title until foreclosure. The first view is commonly called the legal or title theory, and the last the equitable or lien theory, while the second, which is maintained in only a few states, has no distinctive name." 20 (Italics are the writers').

It may also be noted that Professor Campbell, has a "Title" theory, a "Lien" theory, and an "Intermediate" theory as a series of sub-topic headings in the introductory part of his case book on mortgages. ${ }^{21}$ Under the last topic-heading is reported the case of Bradfield v. Hole, ${ }^{22}$ decided by the Supreme Court of Ohio in 1902. In the opinion this statement appears:

"The ground on which ejectment may be brought, is that, as between the mortgagor and mortgagee, after condition broken. the legal title is in the mortgagee."

The court also expressly approves this further statement:

"The mortgage being in equity regarded as a mere security for the debt, the legal title to the mortgaged premises remains in the mortgagor as against all the world, except the mortgagee, and also against him until condition broken, but after condition broken, the legal title, as between mortgagor and mortgagee, is vested in the mortgagee."

It is concluded that Professor Campbell has intended to name Professor Durfee's second view the "Intermediate" theory.

Not only have Professors Durfee and Campbell thus added the foregoing third category in the classification of states, but Professor Durfee has also maintained that his "equitable or lien" theory is not only an "equitable" theory; it is a theory of law as distinguished from equity; it is a development from and modification of the original English common law theory although it is

${ }^{20}$ Durfee, op. cit. supra note 5 , at 587, n. 3.

21 Canipbeli, Cases on niortgages (1926).

2267 Ohio St. 316, 65 N. E. 1008 (1902); CAsrpael, op. cit. supra note 21 , at 24. 
taken from and framed upon the English equity doctrine. To quote him:

"The new conception of the mortgage is often spoken of as the 'equitable theory;' but, whatever terms are used, the new theory is a theory of law promulgated by courts of law . . Taking its shape from the then ancient doctrines of equity, the new theory of law was properly enough denominated an equitable theory just as rules borrowed by the common law from the civil law, such as those of confusion of goods, may properly be called civil law rules, but in either case the transplanted law is common law, and being law the rights recognized and enforced by it are legal rights as distinguished from equitable rights." ${ }^{23}$

Is Professor Durfee's classification of the states based on abstractions of a high degree, ${ }^{24}$ vague and variable conceptions, theories, or is it according to the courts' decisions? He introduces his classification by the declaration that "there are probably no two states in which the law of mortgages is the same in all particulars." But is this peculiar to the law of mortgages? If two states were completely duplicatory in this respect would they inevitably fall into the same class under his scheme of classification? Professor Durfee states that it is held that the legal title passes at the times stated. How many judgments or decrees or "holdings" are entered by a court in a single given case in court involving mortgages-one that "passes the legal title" sooner or later in relation to the date of execution of the mortgage and another which decides and orders whether plaintiff shall have what he asks for? Or does the plaintiff in mortgage cases ordinarily plead for a passing of the legal title as of some particular time?

With these questions all before him the student turns to ask what is this "legal title" and this "lien" to which these writers refer? Mr. Lloyd undertakes to define the term "lien" as used in writings upon "the mortgage" as follows:

" 'Lien' has now come to mean, in a popular sense, any hold which one person has upon the property of another as security for a debt or demand." ${ }^{25}$

Later in his article, however, Mr. Lloyd surrenders in his definitional pursuit and says:

"The word lien, which had at common law a well settled meaning, as well as in equity ... now, for better or worse, has taken in the American courts a broad and somewhat vague significance, approximating roughly to the continental hypothec. ... After all the mortgage transaction that our law has slowly and empiri-

23 Durfee, op. cit. supra note 5, at 599.

24 See supra note 18.

25 Lloyd, op. cit. supra note 15, at 236. 
cally developed is sui generis." ${ }^{26}$ (First italics in last sentence are the writers').

Does Mr. Lloyd mean that the mortgage transaction was not and is not sui generis in English "law"? And does he intend it to be understood that the mortgage transaction is sui generis only in so called "lien states" and is this because of the vagueness of meaning of the term "lien" in such cases? If "the mortgage transaction" has developed according to matters of conception, theory, doctrine, according to whether the legal title passes at one time or another, or whether a mortgage is a "mere lien," has it developed empirically? Is it a matter of empirical development of the law of mortgages that the "lien theory" is really a "Iegal conception" rather than "merely equitable"?

What is this "legal title" in question? Little has been found concerning "the legal title" as the term is used in writings on the mortgage. Few have come to commend it as compared with the number of writers who have championed "the lien" in their expositions of mortgage theories. We therefore leave the question unanswered.

Thus it is that an American law student is introduced to the nature of the American mortgage. The writers of this article are inclined to entertain sympathetically the student's complaint that his instruction in these theories is useful, if at all, only in a way not yet disclosed. From them he has learned little more concerning the law of mortgages than the juxtaposition of the written terms which have been reviewed. The student may well complain that he has been led into a thicket of words, conceivings, theories, doctrine and dogma and left there. Miere generalization concerning the "total nature and effect of a mortgage" may be condemned as the generalizations of a speculative philosophy. ${ }^{27}$ This attempt to report synoptically on the total nature of "the mortgage," to set forth a conceptual entirety of "the mortgage," is the technique of the metaphysician. In the words of a recent author:

"It is the aim of metaphysics to give an account of everything all at once ... At first sight, at any rate, the opposite method of the man of science has much to recommend it. The man of science does not trouble his head about the sorry scheme of

26 Ibid. 245.

27 A modern writer has divided philosophy into two classes: critical philosophy and speculative philosophy. The former consists of an investigation and analysis of our concepts and beliefs. The latter accepts without question the fundamental beliefs, and, by a process of addition and deduction, seeks to "reach some general conclusion as to the nature of the Universe. -." Broad, Scentific Thought (1923) 18 et seq. Possibly because of the innate difficulty of the task and possibly because, at first glance, at least, the work seems largely devoid of practical usefulness, there have been few critical philosophers in legal fields. 
things entire, but looks at one small part of it from one particular point of view to see what he can make of it. ... We cannot experiment with or observe the whole universe." 28

We would reply to the following statement of Professor Durfee. He says :

"The questions of law which are most difficult to answer are the questions of fundamental theory. They are most difficult to answer upon reason because they are so far-reaching in their application as to defy complete understanding and they are most difficult to answer upon authority by reason of the fact that courts, we will not say because of the difficulty of the questions, but because of that commendable conservatism which forbids saying more than is necessary to reach a decision rarely touch upon them." ${ }^{29}$ (Italics are the writers').

Our reply is as follows:

"The man of science and his common-sense forerunners brush aside a vast number of perplexing problems when they decide to disregard metaphysics and go straight to work on particular parts of the physical world for present purposes." 30

We would merely substitute the term "law of mortgages" for the term "physical world."

Let us briefly re-state the words of the alleged theories of mortgage in the United States and then re-examine their application in the light of what the courts have decided in a number of specific cases which have come before them.

Under the "common law or title theory" it is said that the mortgage is considered to be "a conveyance of the legal estate"; "the mortgage is held to pass the legal title to the land at its execution"; "in law.... the mortgagor has no estate whatever." Under the "equitable or lien theory" it is said that the mortgage is considered " $a$ lien on the land, and not an estate in the land"; "the mortgagor, both before and after a breach of the condition, is regarded as the real owner of the land subject to the lien of the mortgage"; this "lien" is a "legal lien," according to Professor Durfee; it is "common law lien" in the sense that it is nonstatutory, at least by and large; ${ }^{31}$ "the mortgage.... is held to pass no title until foreclosure." Under the so called "intermediate theory" "the mortgage . . . is held to pass the title on default." According to Professor Pomeroy's classification we are in doubt whether the "title" and "intermediate" theories constitute his second "method of viewing the mortgage," ${ }^{32}$ which is that as

\footnotetext{
${ }^{28}$ RItChie, SCIENTIFIC MeTHOd (1923) 5.

29 Durfee, op. cit. supra note 5 , at 587 .

30 RITCHIE, op. cit. supra note 28 , at 6 .

31 Durfee, loc. cit. supra note 23.

321 POMEROY, loc. cit. supra note 17.
} 
"between the immediate parties....the legal conception is acknowledged, and the legal rights and duties flowing from the mortgage as a conveyance of the legal estate are recognized and enforced by the courts of law. But as between the mortgagor and his representatives and all other persons not holding under or through the mortgagee, the legal conception has been abandoned, and the equity view has been adopted by all courts." ss

We may note that these theories rest upon the terms "the title," "the legal estate," "the legal title," "the ownership," "the real ownership." The assumption persists that these terms denote unified indivisible concepts. Would it not be conceptually possible and plausible to explode these molecules and to apostatize "titles" and "titles," "ownerships" and "ownerships," ${ }^{36}$ or to give some distinctive name to the atoms? If this is done will it do more harm or inconvenience than to disturb the postulate of the oneness of these conceptions ("estate," "title," "ownership")? Would it not be philosophically convenient to do so? There would then be no difficulty of "the legal estate" or "the legal title" being in a mortgagee. He would get only "a mortgagee's title;" only that would "pass to" and "be in" him. "A mortgagor's title" would remain in a mortgagor. Thereby the whole theory (metaphysics) of mortgages might have been dif-

33 Professor Pomeroy has classified the following as "title" states: Alabama, Arkansas, Connecticut, Delaware, Illinois, Kentucly, Mraine, Maryland, Massachusetts, Mississippi, Missouri, New Hampshire, New Jersey, North Carolina, Ohio, Pennsylvania, Rhode Island, Tennessee, Vermont, Virginia, West Virginia; and the following as "lien" states: California, Colorado, Dakota, Florida, Georgia, Indiana, Iowa, Kansas, Louisiana, Michigan, IIinnesota, Nebraska, Nevada, New York, Oregon, South Carolina, Texas, Utah, and Wisconsin. 1 Poureroy, op. cit. supra note 1, 100 , nn. 1, 2. Also see 3 ibid. $\$ \S 1187,1188$ and notes.

Mr. Jones has classified the following as "title" states: Alabama, Arkansas, Connecticut, Illinois, Maine, Maryland, Massachusetts, XeW Hampshrre, New Jersey, North Carolina, 'Ohio, Peninsylvania, Rhode Islánd, Tennessee, Vermont, Virginia, West Virginia. And the following as "lién" states: California, Colorado, Florida, Georgia, Idaho, Indiana, Iowa, Kansas, Kentucky, Louisiana, Michigan, Minnesota, Montana, Nebraslis, Nevada, New Mexico, New York, North Dakota, Olilahoma, Oregon, South Carolina, South Dakota, Texas, Utah, Washington, and Wisconsin. Ant the following states as adopting the "intermediate theory": Delaware, Mississippi, and Missouri. 1 JonEs, op. cit. sepra note 16, \$ 58. Also see 1 ibid. \$§ 17-57. Cf. CAMrpbell, op. cit. supra note 21, at 24, where Ohio is classified under the "intermediate theory." Also note Mr. Jones" ns: of the Mississippi River as the geographical dividing line between the "title" and the "Iien" states. 1 JoNes, loc. cit. supra note 16.

3* See Wilkins v. French, 20 MIe. 111, 117 (1841), where the molecule if "ownership" has been broken into at least two atoms. This process has been criticised as "presenting the incongruous position that one persoa may be the legal owner for one purpose, and at the same time anothn.person may be the legal owner for another purpose." 1 JONES, op. cit. supris note 16, § 14. But see Ellison v. Daniels, infra note 50, and Stevens v Turlington, infra note 66 . 
ferent-at least in "the title theory states"; and the term "lien" would never have been debased by vagueness in "the lien theory states"; we would have for a mortgagee in the "lien theory states," so called, "a mere mortgagee's title." Quaere, however, what we might support for a formula in an "intermediate theory state," so called. A postulate which involves the destructibility of these molecules with deductions therefrom involving the resulting atoms, might, it seems, be a foundation for a fairly consistent theory of mortgages, but since we believe that a search for consistency as to theory is a fruitless quest, we shall not pursue our suggestions further.

Rather let us turn to the reported cases on mortgages and examine some of them in the light of the alleged divisions of states according to the theories in question. Let us examine the decisions to verify the statement of Professor Durfee on the "far-reaching.... application" of "fundamental theory."

Suppose that $A$, who we shall call a fee simple owner of Blackacre, mortgages it to $B$ in fee simple, let us say, to secure a loan from $B$ equal to one-third of the value of the land. Suppose that $X$ thereafter procures a judgment against $A$ in a common law court and seeks to take execution thereon against Blackacre. Can a law execution pick up a "mere equity" which is said to be no "legal estate" at law in a "title theory state," so called? On the other hand in a "lien theory state," so called, can there be any doubt that the execution will lie, if the mortgagor is "regarded as the real owner of the land subject to the lien of the mortgage?" And in the "intermediate theory states," so called, will the execution lie if there has been default by $A$ ? But if, according to Professor Pomeroy, in 1 non-"lien-theory-states" "as between the mortgagor . . . and all persons not holding under or through the mortgagee, the legal conception has been abandoned, and the equity view has been adopted by all courts" is it not plausible, and therefore logical, to expect that the execution will lie in favor of $X$, if he does not hold "under or through the mortgagee?" If we now turn to the decisions and find, as we do, that they are practically in accord throughout all of the states that the execution will lie, ${ }^{35}$ we conclude as follows: either (1) that any differences in the theories of the nature of a mortgage in the several states are immaterial in this class of cases, or (2) that there is no material difference in the theories of the several states. On either conclusion "fundamental theory" in this situation scarcely has the "far-reaching application" alleged.

But suppose that $B$, the mortgagee, procures a judgment in a

35 Punderson v. Brown, 1 Day 93 (Conn. 1803); Bodwell Granite Co. v. Lane, 83 Me. 168, 21 Atl. 829 (1891); Huntington v. Cotton, 31 Miss. 253 (1856); see Blanchard v. Colburn, 16 Mass. 345, 347 (1820); MeNair v. O'Fallon, 8 Mo. 188, 199 (1843). 
law court against $A$, the mortgagor, for the amount of the mortgage debt. He desires to take execution thereon against Blackacre. Will the conception of the nature of mortgage determine the decision? Is there any doubt under "Iien theory?" Isn't there real doubt under "title" or "intermediate theories," and if, according to Professor Pomeroy, in "non-lien states" the legal conception is acknowledged as between mortgagor and mortgagee. is not this real doubt doubled? Since the decisions are practically uniform that $B$ 's execution will not lie, ${ }^{36}$ we again conclude concerning "fundamental" theory as in the first case.

Let us take a third case. Suppose that $X$ were a judgment creditor of $B$, a mortgagee. Can he have a law execution against the mortgaged land? If "the legal title" has passed to the mortgagee, how can it be denied? In a "lien theory state" how can it be granted? How shall we use Professor Pomeroy's observations on the non-"lien-theory-states" to the effect that the legal conception has been abandoned as between mortgagor and all persons not holding under the mortgagee, but that it does obtain "as between mortgagor and mortgagee and those holding under or through the mortgagee?" What is $X$ 's position as the mortgagee's judgment creditor trying for his execution? Since the decision in the American cases are uniform in denying $X$ 's execution, ${ }^{37}$ we conclude as we have in the other cases concerning the "far reaching application" of "fundamental theory."

Let us turn to another series of cases-those involving dower rights in mortgaged land. Suppose that $A$ executes the mortgage, later marries, and then dies with the mortgage debt unsatisfied. What are the dower rights of $A$ 's widow? Dower has been theoretically predicated upon a beneficial legal seisin of the husband during coverture. ${ }^{38}$ How could it be conceived that $A$, husband-mortgagor, was seised during coverture if "the legal title" and "the legal estate" passed to the mortgagee? =0 In a "lien theory state," can there be any doubt of the widow's

36 Powell v. Williams, 14 Ala. 476 (1848); Goring's Ex'x v. Shreve, 37 Ky. 64 (1838); Atkins v. Sawyer, 1 Pick. 351 (Mrass. 1823) (suggesting, however, that the mortgagee could levy on the mortgaged land for a debt independent of the secured debt); MIcNair v. O'Fallon, supra note 35; see Waller v. Tate, 43 Ky. 529, 531 (1844).

37 Blanchard v. Colburn, supra note 35; Smith v. People's Banl:, 24 Mie. 185 (1844); MIcLaughlin v. Shepherd, 32 Me. 143 (1850); Huntington v. Smith, 4 Conn. 235 (1822). Judge Trowbridge argued strenuously for the view that the mortgagee's interest was subject to execution but could cite no cases in support. Trowbridge, Of Mlortgages, 8 Miass. 551, 558 (1812).

38 Unless changed by statute a widow's dower consists of a life estate in one-third of the lands of which her husband was seized of an estate of inheritance at any time during coverture. 2 BuAcrstose 129 . Cf. early Conn. statute infra, note 41.

39 This argument was often advanced. See arguments of counsel in cases cited infra notes 41 and 47 . 
rights, unless it is because the "lien" conception is one of the law courts as well as of the equity court; that is, does fee simple estate minus "lien" at law and in equity leave "beneficial seisin"? In the light of Professor Pomeroy's remarks on the system in the non-"lien-states," 40 will the widow prevail against third persons who claim under the husband-mortgagor for example, his heirs, personal representative, or grantee? If "the legal conception" is "acknowledged" as between the immediate parties, does that preclude the mortgagor's widow from claiming her dower as against the mortgagee?

The decisions in the American states from the earliest cases are remarkably uniform that the widow in our case wins as against mortgagor's heirs, personal representative, grantee and others who "claim through" him. ${ }^{41}$ At the same time she loses as against the mortgagee. ${ }^{42}$ Again, if the mortgage is executed after marriage, the widow with like uniformity obtains dower against those who "claim through" the mortgagor.43 She prevails against the mortgagee also in this latter case unless she joined in the mortgage. ${ }^{44}$ We again conclude (1) that differences in the theories of the nature of a mortgage in the several states are immaterial in these cases, or (2) that there is no material difference in the theories of the several states.

Let us now assume that $A$ 's mortgage is a purchase-money mortgage; that it was executed after coverture; and that $A$ 's wife did not join in the mortgage. Let us assume that $A$ died

401 POMERoY, loc. cit. supra note 17.

41 Montgomery v. Bruere, 5 N. J. L. 865 (1820), reversing decision in Supreme Court, 4 N. J. L. 260 (1818), denying the widow's dower; Collins v. Torry, 7 Johns. 278 (N. Y. 1810); Hartshorne v. Hartshorne, 2 N. J. Eq. 349 (1840); see Heth v. Cocke, 1 Rand. 344 (Va. 1823). In Fish v. Fish, 1 Conn. 559 (1816), the mortgagor's widow obtained dower against the husband's administrator under a statute then in force which gave dower in land of which the husband died possessed in his own right. Conn. Rev. Stat. (1821) tit. 26, §1. Compare this decision with those of the Connecticut cases cited infra note 50, holding that the mortgagee immediately upon the execution of the mortgage may bring ejectment against the mortgagor without notice.

42 Rands v. Kendall, 15 Ohio 671 (1846); Carll v. Butman, 7 Me. 102 (1830); Woodhull v. Reid, 16 N. J. L. 128 (1837).

43 Wilkin v. French, supra note 34; Cornog v. Cornog, 3 Del. Ch. 407 (1869); Snyder v. Snyder, 6 Mich. 470 (1859); Macauley's Ex'r v. Dismal Swamp Land Co., 41 Va. 507 (1843); see Kissell v. Eaton, 64 Ind. 248, 249 (1878). Contra: Popkin v. Bumstead, 8 Mass. 491 (1812). But see Snow v. Stevens, 15 Mass. 278 (1818).

${ }^{44}$ Sulton v. Jervis, 31 Ind. 265 (1869); Gold v. Ryan, 14 Ill. 53 (1852). A contrary result is reached in those states where the widow's inchoate right of dower is abolished by statute. MicIver v. Cherry, 27 Tenn. 713 (1848); Pickett v. Buckner, 45 Miss. 226 (1871). Or where the claims of creditors are superior to the widow's dower claim. Killinger v. Reidenhauer, 6 Serg. and R. 531 (Pa. 1821); $c f$. Crittenden v. Johnson, 11 Ark. 94 (1850). 
either before or after default but before payment of the mortgage debt. Is his widow entitled to dower from the mortgaged premises? In a so-called "title theory state" her claim might be generally denied by resort to the doctrine that the husband received only a non-beneficial "instantaneous seisin," 45 and that "the title" circuited through the buyer-mortgagor and returned to the vendor-mortgagee, since the mortgage was executed as a part of the same transaction in which the premises were deeded by the vendor. But how can this theory be advanced in a state which is said to have "the lien theory" of mortgage when "the title" must stop (that is, it is "short circuited") with the mortgagor and merely "a lien" is let back to the mortgagee? Yet, if, in Professor Pomeroy's non-"lien-theory states," the legal conception of mortgages is denied as between mortgagor and third persons not claiming under or through the mortgagee, will "the title" have completed the circuit back to the mortgagee, when and as the widow of the mortgagor claims dower? Does she "claim through" or "under" the mortgagee; is she in the same position as the mortgagor for the question at hand? How is the doctrine of "instantaneous seisin" of the purchase-money mortgage with its circuit of the "title" to be reconciled with the "intermediate theory" of mortgage whereby "the title" is in the mortgagor until default?

Suffice it to note that the rule seems to be uniform that the widow's claim to dower as against the mortgagee in such a case is not allowed.s6 It likewise appears to be well settled that the widow's claims to dower as against those who "claim through" the mortgagor, for example, his heirs, personal representative, or grantee are allowed in such case..$^{\text {st }}$

Let us test the "far-reaching application" of "fundamental theory" by another case. Suppose the mortgagee died before foreclosure. Will his widow obtain dower? Under "the title theory" must not her claim be supported? Likewise under the "intermediate theory" must not the widow win, at least, if the mortgagee died after the mortgagor's default. Could it not be an $a$ fortiori case for her if her husband were a purchase-money mortgagee-at least in a title theory state? However, in spite of any logical perfection of her conceptual position no American

45: "Instantaneous seisin" is not sufficient to support dower. Co. IITT. *316; Mayburry v. Brien, 15 Peters 21 (U. S. Sup. Ct. 1841).

46 Holbrook v. Finney, 4 Mass. 566 (1808); Stow v. Tifit, 15 Johns. 458 (N. Y. 1818); see Cass v. Martin, 6 N. H. 25, 26 (1832).

47 Campbell v. Knights, 24 ITe. 332 (1844); Carter v, Goodin, 3 Ohio St. 75 (1853) ; Hitchcock v. Harrington, 6 Johns. 290 (N. Y. 1S10); Stopprlbeim v. Shulte, 1 Hill 200 (S. C. 1833); Brovn v. Duncan, 4 IIcCord 816 (S. C. 1387). Contra: Vervee v. Vervee, 2 Erev. 211 (S. C. 1807). 
case has been found which has awarded the mortgagee's widow dower against anyone.48

We will look at one more group of cases-the possession cases. The American cases appear to be in accord that if the mortgagor and mortgagee expressly or impliedly agree that the mortgagor shall have possession the mortgagor can plead that agreement to bar the mortgagee's action to recover possession in defiance of that agreement. ${ }^{49}$ A'gain, it seems that differences in theories do not count.

In cases, however, where there is no such agreement concerning possession and no statute in point there are three classes of decisions just as there are three theories of mortgage, as follows: (1) those which hold that the mortgagee can recover possession of the mortgaged land, at least after demand therefor, although the mortgagor has not defaulted; ${ }^{50}$ (2) those which hold that the mortgagee is entitled to immediate possession if and when the mortgagor defaults; ${ }^{51}$ (3) those which deny the mortgagee an action for possession even after default if brought prior to foreclosure..$^{52}$

It is inferred that perhaps Professor Durfee's three theories of mortgage are entwined about these three classes of decisions as follows: (1) That "the title theory" refers to the rule that the mortgagee is entitled to possession forthwith upon execution of the mortgage; (2) that "the intermediate theory" signalizes the rule that the mortgagee is entitled to possession only upon or after default; (3) that "the lien theory" refers to the rule that the mortgagee is not entitled to possession prior to foreclosure. It is quite clear that if these three theories are respectively predicated upon these particular decisions ${ }^{53}$ the terms

48 For dicta to the effect that mortgagee's widow is not dowable, sco Pickett v. Buckner, supra note 44, at 245; Reed v. Shepley, 6 Vt. 602, 609 (1834); Crittenden v. Johnson, supra note 44, at 104.

49 Hartshorn v. Hubbard, 2 N. H. 453 (1822); Wales v. Mellen, 1 Gray 512 (Mass. 1854); Clay v. Wren, 34 Me. 187 (1852).

50 Dougherty v. Kercheval, $8 \mathrm{Ky} .52$ (1818); Brown v. Cram, 1 N. H. 169 (1818); cf. Ellison v. Daniels, 11 N. H. 274 (1840) (mortgagor may recover possession from a third person). Early Connecticut cases held that the mortgagee could maintain ejectment without notice to the mortgagor to quit. Rockwell v. Bradley, 2 Conn. 1 (1816) (4 judges dissenting); Wakeman v. Banks, 2 Conn. 445 (1818) (3 judges dissenting).

${ }_{51}$ Mindy v. Monroe, 1 Mich. 68 (1848); Ely v. McGuire, 2 Ohio 223 (1823) ; Bradfield v. Hale, supra note 22; see Benton Land Co. v. Zeitler, 182 Mo. 251, 272, 81 S. W. 193, 199 (1904).

52 Runyan v. Mersereau, 11 Johns. 534 (N. Y. 1814); Duty v. Graham, 12 Tex. 427 (1854) ; Burks v. Buske, 141 S. W. 337 (Tex. Civ. App. 1911); see Brown v. Snell, 6 Fla. 741, 744 (1856).

53 This belief is strengthened by a statement of Mr. Jones who, after giving the varying rules regarding the right of possession, states: "This is the great difference resulting from these different theories." 1 JONES, op. cit. supra note $16, \S 15$. 
in which each of the theories is expressed,-title, estate, ownership, lien-are more general than is necessary to report the particular rule of law, and that the specific rule of law is not mentioned in their terms. ${ }^{54}$ We suspect that Professor Pomeroy's two methods of viewing "an ordinary mortgage" ignore the difference of the decisions in the "title" and "intermediate" theory states, so-called. However, we are not entirely certain in either case, but three groups of decisions associated with threc theories is suggestive if not persuasive under the circumstances.

If we have caught the correct basis for classification of mortgage theories in the American states we should note how "farreaching" are their "fundamental" theories in these particular possession cases. Which begat the other-did "the lien theory" determine that the mortgagee did not have the right to possession forthwith, in the first American "lien theory state," or did the decision by the court of the American state first to decide that the mortgagee did not have the right to possession forthwith determine that that state was the first "lien theory state"? The same question should be put concerning the other theories. If the theory determined the decision, to what did the terms of the theory refer? And what determined the theory?

If the three theories are predicated upon the three different classes of decisions concerning a mortgagee's right to possession and the classification is based upon those rules, quite clearly these theories are ex post facto generalities; quite clearly they had no "far reaching application" in fixing the decisions in these cases-they come only to report the result of the decisions in their very general terms.

But it may be denied that these several theories are confined to reporting in general terms the rules regarding possession. It may be, and apparently is urged that they represent a basis of classification of the American states and that in a given state a given theory permeates, at least by-and-large, its whole mortgage structure; that the states can be classified as "title," "intermediate," or "lien" to give a prevailing if not a complete picture of a mortgage."

We are inclined to criticize this position. We believe that a supreme court of a given state uses or refrains from using one theory in one case and uses or refrains from using that theory or another theory in another case, depending upon the judges' sense of convenience and the matters which stimulate them in the particular case.

Let us examine what the supreme court of North Carolina has written about the nature of a mortgage in a variety of cases which have been picked at random, as was the state. In the light of the statements of the supreme court, is North Carolina

\footnotetext{
${ }^{54}$ See observations of Professor Cook, op. cit. supra note 12, at 899.
} 
"a title theory state," "an intermediate theory state," or "a lien theory state"?

"We have adopted the common-law rule that a mortgage carries the legal title to the mortgagee, which he holds in trust for the security of his debt. A mortgage of land is not a mere pledge of chattel security. . . As the mortgagee of land has the legal title, he is entitled to the possession."

"He [the mortgagor] has not any legal estate. But in equity he has the entire estate subject to the incumbrance of the debt secured . . . The current of modern opinion is in favor of regarding a mortgage as simply an incumbrance, diminishing the value, but not the quality of estate, just as a docketed judgment does." ${ }_{5 B}$

"In many of the states the strict legal relations of the parties resulting from the making of a mortgage have been changed, 'for the most part by statute', remarks a recent author, 'so that a mortgage is regarded as a mere pledge, and the rights and remedies under it are wholly equitable, so that a second system has grown out of the first.' 1 Jones, Mortg., Sec. 17. It is held that the mortgage, though conveying land, passes but a chattel interest incidental to and partaking of the nature of the debt intended to be protected, and hence upon the death of the mortgagee it may be assigned by his personal representative. Such is not the law in this state, and the distinction is maintained between the legal estate in the mortgagee and the equitable estate in the mortgagor, created by the execution of the mortgage deed, while the latter is subject to dower and to sale under execution." 57

"It is well settled that the mortgagor is the tenant of the mortgagee. . . ." 58

"A mortgages his land to pay $\$ 1,000$. He has a pure and simple equity to call for the legal title upon paying the $\$ 1,000$. All of which appears upon the mortgage deed. His equity may be sold, and the purchaser of his equity has the right to call for the legal title, upon paying $\$ 1,000$.

But where the transaction had become complicated, part of the debt paid, and part not paid, or subject to set offs, or other equities, . . it was not an unmixed equity. . . No equity can be sold under the Statute unless the sale of the equity can draw to it the legal estate, which cannot be if the legal estate is hitched to some other equity: because then equal forces are pulling in opposite directions." "59

"In some states, where a mortgage is regarded only as a secur. ity for the debt and the legal title is not considered as in the mortgagee, it has been held that a mortgagee who is not in actual possession of the land may acquire the title by purchase at a tax sale as against the mortgagor. But this is not the rule with us.

\footnotetext{
55 Weathersbee v. Goodwin, 175 N. C. 234, 95 S. E. 491, 493 (1918).

56 State v. Ragland, 75 N. C. 12,13 (1876).

5t Williams v. Teachey, 85 N. C. 402,404 (1881).

58 Parker v. Banks, 79 N. C. 480,483 (1878).

59 Tally v. Reid and Sossamer, 72 N. C. 336,338 (1875).
} 
The legal estate passes to the mortgagee, and he holds it not only in trust for himself, but also for the mortgagor:." 60

"There are a few states where the contrary doctrine prevails - . the mortgage being regarded as merely subsidiary to the debt, an incident to the principal, the shadow which follows and depends upon the substance.

This is not the view taken in this state of these relations. - . The note evidencing the debt is the personal obligation of the debtor-his undertaking; the mortgage is a direct appropriation of property to its security and payment." 61

"When a debt is secured by a mortgage, the debt is the principal and the mortgage only the incident, security for the debt." 62

"When mortgaged lands are in the possession of a tenant, and a foreclosure is had during the term of the lease, nothing else appearing, the mortgagor is entitled to collect all the rent that is due at the time of sale . . . The title to the rent is dependent on that of the property. . . " "63

"The mortgagee is the depository of the legal estate, and holds it for the security of his own debt and then in trust for the mortgagor. He may enter upon the land or recover it by action for the purposes of the trust. He may sell and dispose of the land under the power conferred. Is not his influence potential, and the mortgagor's condition dependent, if not to the same degree, as in other cases of trust?" os

"Where there is the relation of attorney and client, guardian and ward, trustee and cestui que irust, although dealing in respect to the fund is not prohibited in this court, yet it is watched with much jealousy, and the attorney, guardian or trustee is required to show affrmatively, that such dealing was fair, and for a reasonable consideration; so as to exclude the inference, that advantage was taken of the relation existing between the parties-that of dependence on one side, and a duty to protect on the other.

This principle does not apply to the relation of mortgagor and mortgagee. Dependence and the duty of protection are not involved in the relation. The parties have definite rights, stand at 'arms length', and may deal, subject only to the ordinars principle. . . ." 65

"The decisions in this state are to the effect that as between the mortgagor and mortgagee, the legal title to the mortgaged premises is vested in the mortgagee, while the mortgagor is looked upon as the equitable owner of the land. This relative position continues until the land is redeemed or the mortgage is foreclosed. . . . Where there is no agreement to the con-

${ }^{60}$ Cauley v. Sutton, 150 N. C. $327,329,64$ S. E. 3,4 (1909).

${ }^{61}$ Copehart v. Dettrick, 91 N. C. 344, 352 (1884).

62 Humphrey v. Stephens, 191 N. C. 101, 104, 131 S. E. 353, 385 (1925).

63 Hercer v. Bullock, 191 N. C. 216, 131 S. E. 580, 531 (1926).

64 MIcLeod v. Bullard, 86 N. C. 210, 216 (1382).

es Chapman v. Miull, 42 N. C. 292, 294 (1S51). 
trary, certainly after default the mortgagee is entitled to enter and to hold the land until redeemed; and he may maintain an action in ejectment therefor, even against the mortgagor himself. . . . Such rights are given to the mortgagee to enable him to protect his security, prevent waste, and keep the land from being lessened in value in any unlawful manner. In so far as it is necessary to accomplish these purposes, the mortgagee is considered and treated in law as the holder of the legal title; but otherwise his interests are viewed from a different standpoint. . . For purposes other than those mentioned above, the mortgage is to be considered as an incident to the debt which is the principal consideration, while, for the purposes of security, in this jurisdiction, it is treated as a direct appropriation of the property. - . But until foreclosure, or at least until possession taken, the mortgage, as a general rule, is regarded in the light of a chose in action to be dealt with according to the principles of equity . . . In this state mortgages are practically the same as at common law, with the exception of the mort. gagor's equity of redemption and its incidents. We adhere to the doctrine that the legal title passes to the mortgagee, subject to the equitable principle that this passage of the legal title is primarily by way of security for the debt, and that for all other purposes the mortgagor is regarded as the owner of the land." ou

"By proper indorsement of the payees the plaintiff became a holder of the note in due course; but, as the mortgage was not transferred or assigned, the legal title to the mortgaged property remained in the mortgagees. In these circumstances the plaintiff held the note without notice of any infirmity in it or any defect in the title of the payees, and in the absence of an agreement to the contrary the security followed the note . . . The mortgagees held the legal title in trust for the benefit of the plaintiff who, as holder of the note, was vested with an equity to have the land sold under the mortgage and the proceeds applied in payment of the debt." 67

"Certainly the Connor Act applies to the registration of mortgages as against creditors and purchasers for value, which are included in the term 'conveyances'. Mortgages have been uniformly held by this court to be conveyances of the legal title and require the formality of a conveyance in their assignment as against purchasers for value, and therefore as against purchasers the legal title vested in the mortgagee comes within the provisions of the registration act." 68

"The importance of the question to the profession and to the register of deeds throughout the state is obvious. If the recording of a land mortgage in a chattel mortgage book . . . is sufficient to create a lien upon' real estate, then every attorney must search and examine every sort of index . . . Upon the other hand, ought the holder of a lien to be deprived of the

${ }^{66}$ Stevens v. Turlington, 186 N. C. $191,194,119$ S. E. 210,211 (1923).

cr Citizens' Savings Bank \& Trust Co. v. White, 189 N. C. $281,283,126$ S. E. 745,746 (1925).

68 First National Bank v. Sauls, 183 N. C. $165,169,110$ S., E. 865,867 (1922). 
benefit thereof when he delivers it to the register of deeds for recording and it is indexed and cross-indexed in one of the general indexes kept in his office?" ${ }^{9}$

Thus in North Carolina the nature of "a mortgage" may be summarized as follows: it "carries the legal title to the mortgagee, which he holds in trust for the security of his debt," it is not "a mere pledge of chattel security"; while the mortgagor: has not any legal estate, yet in equity he has "the entire estate subject to the incumbrance," the mortage is "simply an incumbrance"; "the law in this state" does not regard the mortgage "as a mere pledge," "the distinction is maintained between the legal estate in the mortgagee and the equitable estate in the mortgagor"; "the mortgagor is the tenant of the mortgagee"; the mortgagor, has "a pure and simple equity to call for the legal title"-at least where the transaction has not become complicated by equities pulling in the opposite direction; the mortgage is not regarded merely "as a security for the debt," "the legal estate passes to the mortgagee, and he holds it not only in trust for himself, but also for the mortgagor," it is "a direct appropriation of property to its security and payment," and is not regarded "as merely subsidiary to the debt, an incident to the principal, the shadow which follows and depends upon the substance," yet "the debt is the principal and the mortgage only the incident, security for the debt," and the mortgagor receives the rent prior to foreclosure for "the title to the rent is dependent on that of the property," yet "the mortgagee is the depositary of the legal estate, and holds it for the security of his own debt and then in trust for the mortgagor" but "this principle does not apply to the relation of mortgagor and mortgagee. Dependence and the duty of protection are not involved in the relation. The parties . . . stand at 'arms length' . . ."; the mortgage is "a conveyance," is "a lien" . . . , etc.

We are certain, after reviewing the reported opinions of the courts in some of the other American states, that North Carolina is not "anomalous" or in an exceptional "confusion" concerning its theory (i.e., theories) of a mortgage. We are reluctant to refer to the situation as one of "confusion" because the opinions of the North Carolina court were approached with a feeling that, true to life generally, questions in mortgage law are many and complex and that a court confronted with a concrete case with its live parties presenting conflicting claims is likely to be influenced by the particular case to the prejudice of any simple generalization, general legal principles, legal theory or conception of "a mortgage," and that the symmetry of any doctrine or

${ }^{69}$ Merchants' \& Farmers' Bank v. Harrington, 137 S. E. 712, 713 (N. C. 1927). 
conception will be lost in that "wilderness of single instance." Unless it is postulated that the establishment and preservation of such a symmetry is the primary, fundamental, far-reaching function of the court we do not criticize it for its "variations." "

If there are some rules of mortgage law which are uniform throughout the states, two, three or more different theories to the contrary notwithstanding, and if a given state will use or refrain from reciting a given theory in a given case depending upon whether it does or does not, why, then, do these theories recur in the opinions? Certainly the text writers have not made these several theories out of whole cloth. At least for the most part they are recited in opinions of the judges every now and then and more or less at length.

Without presuming to declare why judges behave like judges, we do submit that the writing of opinions couched in one or more terms which are more, rather than less, abstractions, in terms of generalizations, general legal principles, legal doctrine or legal theory, is a problem involving the functions of language. Without insisting that there is an exact delineation in the two concepts, we believe, however, that the words reporting the theories, doctrines and generalizations which are under consideration: are not used as symbols designed to be descriptive, but rather to be emotive. They are "one word more" in soliciting approval, in urging plausibility, for a particular judgment. As suggestive we quote the following from Messrs. Ogden and Richards :

" 'When language is once grown familiar', says Berkeley, 'the hearing of the sounds or sight of the characters is often immediately attended with those passions which at first were wont to be produced by the intervention of ideas that are now quite omitted.' From the symbolic use of words we thus pass to the emotive; and with regard to words so used, as in poetry, Ribot has well remarked that they no longer act as signs but as sounds; they are musical notations at the service of an emotional psychology.' So that though at this extreme limit 'metaphysical reasoning may be intellectually quite incomprehensible; though, that is to say, it may actually become 'vocem proferre et nihil concepere', it acquires by compensation', as Rignano says, 'un emotive signification which is peculiar to it, i.e., it is transformed into a kind of musical language stimulative of sentiments and emotions'. Its success is due entirely to the harmonious series of emotional echoes with which the naive mind responds -et reboat regio cite barbara bonbum." 71

And in conclusion we would quote from the same authors as follows:

70 That the statement of theory in one case is different from that in another case clearly does not mean that the decision in the former case is overruled. See the North Carolina cases, supra notes 55-69.

71 Ogden and Richards, The Meaning of Meaning (2d ed. 1927) 42. 
"And words may come between us and our objects in countless subtle ways, if we do not realize the nature of their power. In logic, as we have seen, they lead to the creation of bogus entities, the universals, properties and so forth . . . By concentrating attention on themselves, words encourage the futile study of forms which has done so much to discredit Grammar; by the excitement which they provoke through their emotive force, discussion is for the most part rendered sterile; by the various types of Verbomania and Graphomania, the satisfaction of naming is realized, and the sense of personal power factitiously enhanced." 72

72 Ibid. 45.

Limitations of space have prevented a critical consideration of the sounds "a mortgage," "the mortgage," "the ordinary mortgage." It is clear, however, when the several fact-transactions are identified which are included under the term "mortgage," "the mortgage," or "the ordinary mortgage" in common usage, that there are mortgages and mortgages not only as a matter of difference in fact-pattern but also in matter of court decisions and in matter of recital of legal theory; that in the same type of case a given court may write of "lien theory" concerning one type of fact-pattern and of "title theory" concerning another fact-pattern although the issue is the same in both cases. The decision may be the same; it may not be the same. These matters are left to a later consideration. 